\title{
PROJEKT OFERTY TURYSTYKI FILMOWEJ JAKO PRÓBA UROZMAICENIA POLSKIEJ OFERTY WYJAZDOWEJ DO IRLANDII W 2018 ROKU $^{1}$
}

\section{Wstęp}

Irlandia to kraj bogaty w walory przyrodnicze i kulturowe, w którym elementy współczesne przeplatają się z folklorem i tradycjami. Na terenie tego kraju występują zarówno obszary nizinne, obfitujące $\mathrm{w}$ jeziora, bagna i torfowiska, jak i klifowe wybrzeża, poprzecinane wciętymi w ląd zatokami. Wśród atrakcji kulturowych Irlandii znajdują się zabytki architektoniczne, muzea, obiekty sakralne. Odbywają się tam również wydarzenia i imprezy o charakterze kulturowym, religijnym czy sportowym (Kosmulska 2005).

Liczba turystów odwiedzających Irlandię wzrasta z każdym rokiem, oscylując obecnie w granicach $10 \mathrm{mln}$ (dane na 2017 r.) (UNWTO. Tourism highlights, 2017). Irlandia pojawia się również w ofercie turystycznej skierowanej do Polaków. Liczba proponowanych co roku turnusów wskazuje, że wycieczki do tego kraju cieszą się tu dużym zainteresowaniem. Mimo to oferta turystyczna, przedstawiana na stronach internetowych biur podróży dla tego kierunku wyjazdu, niemalże nie różni się u poszczególnych touroperatorów.

W celu urozmaicenia pojawiających się na polskim rynku turystycznym propozycji wyjazdowych do Irlandii przygotowano potencjalną ofertę wyjazdową, wzbogaconą o motyw tematyczny związany $\mathrm{z}$ turystyką

1 Artykuł powstał na podstawie pracy licencjackiej pt. Atrakcyjność turystyczna Irlandii, napisanej w Uniwersytecie Marii Curie-Skłodowskiej w Lublinie pod kierunkiem dr hab. Wioletty Kałamuckiej. 
filmową. O jej popularności świadczy fakt, że prawie w każdym z europejskich państw można znaleźć produkt turystyczny odwołujący się do tej tematyki, np. szlak - Niemiecki Szlak Baśniowy, event - Bloomsday w Dublinie, czy park tematyczny - Disneyland we Francji. W niniejszym artykule przedstawiono ofertę wyjazdową opartą na zwiedzaniu atrakcji i miejsc związanych z filmami, do których zdjęcia kręcono w Irlandii.

Celem artykułu jest przeanalizowanie i porównanie ofert wyjazdowych do Irlandii dostępnych w polskich biurach podróży oraz zaprezentowanie autorskiej propozycji wycieczki tematycznej pt. „Irlandia na dużym ekranie", będącej próbą urozmaicenia istniejącej na polskim rynku oferty wyjazdowej do Irlandii.

Metodą badawczą wykorzystaną w pracy był przegląd dostępnej literatury naukowej, przewodników i portali internetowych. Ponadto zastosowano analizę dostępnych na rynku polskim ofert turystycznych do Irlandii, których pobyt wynosił więcej niż pięć dni.

\section{Turystyka filmowa $w$ świetle literatury}

Omawiana $\mathrm{w}$ artykule potencjalna oferta turystyczna to produkt związany z turystyką kulturową, a dokładniej z jednym z jej rodzajów, jakim jest turystyka filmowa. Turystykę filmową definiuje się, jako: „wszelkiego rodzaju podróże turystyczne śladami gwiazd filmu (aktorów, reżyserów) i ich dzieł, stwarzając okazję do głębszej refleksji przeżywania utworów" (Stasiak, 2009). W ramach turystyki filmowej mówi się o:

turystyce biograficznej, której głównym celem jest zwiedzanie: muzeów biograficznych słynnych gwiazd filmowych, miejsc z nimi związanych, odwiedzanie grobów ludzi związanych z kinem, udział w festiwalach filmowych, czy też spotkania $\mathrm{z}$ idolami itp. oraz turystyce fikcji filmowej, czyli wędrowanie w poszukiwaniu (nie zawsze nawet prawdziwych) plenerów filmowych i telewizyjnych, czynny i bierny udział w plenerowych inscenizacjach, warsztatach filmowych i spektaklach teatralnych, podróżowanie szlakami bohaterów filmowych, czy też rodzinny wypoczynek w filmowych parkach rozrywki (Stasiak, 2009).

$\mathrm{Z}$ bardziej ekonomicznym podejściem do definicji turystyki filmowej spotykamy się u Zmyślonego (2001). Według tego badacza sztuka filmowa, jako część kultury, pobudza rozwój turystyki, w wyniku czego w jej obrębie występuje zjawisko polegające na przemieszczaniu się osób poza miejsce zamieszkania oraz związany z tym transfer pieniądza - pobu- 
dzany miejscami, atrakcjami i wydarzeniami, których wspólną cechą jest film. Obiekty, czy też wydarzenia związane z kinem mogą wpływać na generowanie ruchu turystycznego i co za tym idzie - wzrost dochodów $\mathrm{z}$ turystyki w danym miejscu lub obiekcie. Dlatego coraz częściej możemy się spotkać w biurach podróży $\mathrm{z}$ tematycznymi ofertami turystycznymi.

Pojęcie oferty turystycznej jest terminem ekonomicznym, który należy rozumieć jako zespół elementów ją tworzących, ujawniający możliwości podażowe sprzedawcy, będący propozycją sprzedaży produktów i zachętą do kupna, co stanowi podstawę do zawarcia transakcji (umowy kupna-sprzedaży) (Wojciechowska, Florczak, 2005; Dębski, 2006).

Natomiast Panasiuk (2014), opierając się na wyżej przedstawionej definicji, dodaje, że na ofertę turystyczną składają się takie elementy, jak: podmiot oferujący (oferent), produkt (w ujęciu strukturalnym), cena produktu, jakość produktu (wartości użytkowe, które go charakteryzują), czas obowiązywania oferty oraz warunki sprzedaży (płatność, dostawa, gwarancja, możliwość odstąpienia od umowy).

Warto zauważyć, że turystyka filmowa wiąże się z turystyką literacką. Wiele filmów pojawiających się w kinach jest tworzonych na podstawie bestsellerów książkowych, a głównym motywem producentów do zekranizowania publikacji jest jej rozpoznawalność wśród czytelników. Jako przykład można tutaj podać Władcę pierścieni J.R.R. Tolkiena, czy też serię powieści Harry Potter J.K. Rowling.

Co więcej, należy zaznaczyć, że filmy te wpłynęły na miejsca, w których je nagrywano, zmieniając całkowicie ich wizerunek. Tak więc przykładowo Nowa Zelandia stała się krajem powszechnie utożsamianym z opowieścią o Śródziemiu, gromadzącą corocznie rzesze turystów chcących podążyć śladami bohaterów książek Tolkiena. Duża popularność filmu zachęciła producentów do zekranizowania nowej serii filmów Hobbit, odwołującej się do wcześniejszej trylogii. Na potrzeby turystyczne zbudowano replikę wioski Hobbitów w miejscowości Matamata, potocznie zwanej Hobbitonem, będącej obecnie jedną z najchętniej odwiedzanych atrakcji kraju (Stasiak, 2009).

Statystyki podają, że w 2000 r. liczba turystów odwiedzających Nową Zelandię wynosiła 1,7 mln osób. Po wprowadzeniu do kin trylogii o Śródziemiu (2001, 2002, 2003) liczba turystów zaczęła rosnąć i w 2006 r. wynosiła 2,4 mln odwiedzających (Stasiak, 2009). Równie duży wzrost widzów zanotowano po premierze ostatniego filmu serii Hobbit, który pojawił się w kinach w grudniu w 2014 r. Liczba odwiedzających Hobbiton (Matamata) w marcu 2015 r. wyniosła 360 tys. osób - dla porównania 
w marcu 2014 r. liczba widzów osiągnęła 232 tys. osób (w marcu 2011 r. - 33 tys. osób) (Insights).

Znaczną popularnością cieszy się turystyka filmowa w dużych miastach, takich jak np. Londyn, Paryż czy Barcelona. W Londynie turyści mają możliwość zwiedzania miejsc i obiektów widzianych w filmach i serialach, m.in.: Harry Potter, Sherlock Holmes, James Bond, Notting Hill, Dziennik Bridget Jones (Londyn. Bond i nie tylko, 2017). Poza miejscami i obiektami występującymi w rzeczywistości w panoramie Londynu na potrzeby turystyki powstają miejsca specjalnie tworzone dla fanów danego filmu lub serialu. Tak oto wielbiciele Harrego Pottera mogą odwiedzić peron 9 i 33/4 na stacji kolejowej Kings Cross, a zwolennicy Sherlocka Holmesa mają możliwość stanąć pod drzwiami jego domu na Baker Street 221b.

\section{Irlandia w ofercie polskich biur podróży}

W 2018 r. wycieczki do Irlandii można było wykupić w trzech biurach turystycznych - Itaka, Rainbow oraz Logos Tour. Wszystkie oferowały wyjazdy o charakterze wycieczki objazdowej z co najmniej tygodniowym pobytem $w$ tym kraju.

Biuro podróży Itaka dysponowało 9-dniową ofertą o nazwie „W Krainie Leprikonów". Proponowało ono osiem terminów, w okresie od 30 kwietnia do 18 września. Wśród świadczeń, z których mogli skorzystać klienci, znalazły się: przelot, przejazd autokarem, osiem noclegów w hotelach dwui trzygwiazdkowych, w pokojach dwuosobowych z łazienką, siedem śniadań, opieka pilota oraz ubezpieczenie KL i NW. Ramowy plan wyjazdu przedstawiono $\mathrm{w}$ tab. 1.

Biuro podróży Rainbow przygotowało dla turystów 10-dniową wycieczkę objazdową o nazwie „Irlandia i Irlandia Północna - legendy wykute w skałach". W zakres świadczeń biura oferowanych klientom podczas wycieczki wchodziły: dziewięć noclegów w hotelach trzy- i czterogwiazdkowych, znajdujących się poza centrum miasta, w pokojach dwuosobowych z łazienką, dziewięć śniadań kontynentalnych i obiadokolacji w hotelach, przelot, przejazd autokarem, opieka pilota oraz ubezpieczenia (KL, NNW, CP, Assistance i bagażu). Terminy wyjazdów oferowane przez biuro Rainbow obejmowały 11 turnusów, spośród których pierwszy z nich zaczynał się 27 kwietnia, a ostatni 7 września. Wszystkie wycieczki rozpoczynały się na lotnisku w Warszawie. Miejsca odwiedzane podczas wyjazdu przedstawiono $\mathrm{w}$ tab. 2 . 
Tab. 1. Plan trasy wycieczki „W krainie Leprikonów”, oferowanej przez biuro podróży Itaka w 2018 r.

\begin{tabular}{|c|l|}
\hline Dzień & \multicolumn{1}{|c|}{ Elementy oferty } \\
\hline 1 & Przelot do Dublina \\
\hline 2 & $\begin{array}{l}\text { Dublin (katedra św. Patryka, Trinity College, Grafton Street); fakultatywnie } \\
\text { Muzeum Guinness Storehouse }\end{array}$ \\
\hline 3 & Wicklow (dwór Powerscourt); Dolina Glendalough (klasztor św. Kevina) \\
\hline 4 & Kilkenny (Zamek Kilkenny); Cashel (Rock of Cashel) \\
\hline 5 & $\begin{array}{l}\text { Pierścień Kerry (trasa wzdłuż wybrzeża Oceanu Atlantyckiego, farma owiec } \\
\text { Kissane, Muckross House) }\end{array}$ \\
\hline 6 & Bunratty Folk Park (odtworzona wioska); Burren; Klify Moheru \\
\hline 7 & Galway; Park Narodowy Connemara; Kylemore (Kylemore Lough) \\
\hline 8 & Londonderry; Grobla Olbrzyma; Belfast \\
\hline 9 & Powrót do Polski \\
\hline
\end{tabular}

Źródło: opracowanie własne na podstawie danych pobranych ze strony internetowej biura podróży Itaka.

Tab. 2. Plan trasy wycieczki „Irlandia i Irlandia Północna - legendy wykute w skałach”, oferowanej przez biuro podróży Rainbow w 2018 r.

\begin{tabular}{|c|l|}
\hline Dzień & \multicolumn{1}{|c|}{ Elementy oferty } \\
\hline 1 & Przelot do Dublina \\
\hline 2 & $\begin{array}{l}\text { Dublin (Trinity college, Phoenix Park, Temple Bar, katedra św. Patryka, Mu- } \\
\text { zeum Narodowe, deptak Grafton Street); fakultatywnie Muzeum Guinness } \\
\text { Storehouse }\end{array}$ \\
\hline 3 & Belfast \\
\hline 4 & Grobla Olbrzyma; Dunluce Castle \\
\hline 5 & Marbel Arch Caves; Killary Harbour \\
\hline 6 & $\begin{array}{l}\text { wyspa Inishmore (ford Dun Aengus, kościół Teampall Bheanain) albo Galway } \\
\text { (oceanarium, Park Narodowy Connemara, dawna kopalnia ołowiu i srebra) }\end{array}$ \\
\hline 7 & $\begin{array}{l}\text { Burren; Klify Moheru; Bunratty (zamek Bunratty Castle, skansen Bunratty Folk } \\
\text { Park) }\end{array}$ \\
\hline 8 & Pętla Kerry; Muckross House \\
\hline 9 & Rock of Cashel; Dublin \\
\hline 10 & Powrót do Polski \\
\hline
\end{tabular}

Źródło: opracowanie własne na podstawie danych pobranych ze strony internetowej biura podróży Rainbow.

Trzecie biuro podróży - Logos Tour - proponowało swoim klientom 8-dniową wycieczkę objazdową "Irlandia 2018". Podobnie jak w przypadku wcześniejszych ofert wśród świadczeń dla klientów można znaleźć: 
siedem noclegów w hotelach dwu- i trzygwiazdkowych, w pokojach dwuosobowych z łazienką, śniadania po każdym noclegu w hotelu, przelot, przejazd autokarem, opiekę pilota oraz ubezpieczenie KL, NW i bagażu. Biuro dysponowało trzema terminami w okresie od 21 maja do 30 lipca. Każdy z turnusów zaczynał się w Warszawie. Ramowy plan wyjazdu przedstawiono $\mathrm{w}$ tab. 3 .

Tab. 3. Plan trasy wycieczki „Irlandia 2018”, oferowanej przez biuro podróży Logos Tour

\begin{tabular}{|c|l|}
\hline Dzień & \multicolumn{1}{|c|}{ Elementy oferty } \\
\hline 1 & $\begin{array}{l}\text { Przylot do Dublina; Dublin (katedra św. Patryka, City Hall, Bank of Ireland, } \\
\text { kompleks Trinity College) }\end{array}$ \\
\hline 2 & $\begin{array}{l}\text { Cashel (Rock of Cashel); Blarney (zamek); Cork (spacer - French Church Street, } \\
\text { Carey's Lane, St. Patrick Street) }\end{array}$ \\
\hline 3 & $\begin{array}{l}\text { Pierścień Kerry (farma owiec Kissane, Sneem Village, Cahirciveen, Muckross } \\
\text { House) }\end{array}$ \\
\hline 4 & Bunratty (zamek i wioska); Klify Moheru (O'Brien's Tower) \\
\hline 5 & Galway; Góra św. Patryka (Croagh Patrick); Londonderry \\
\hline 6 & Grobla Olbrzyma; Bushmills; Belfast \\
\hline 7 & Belfast; Dublin (Dwór Powerscourt) \\
\hline 8 & Powrót do Polski \\
\hline
\end{tabular}

Źródło: opracowanie własne na podstawie danych pobranych ze strony internetowej biura podróży Logos Tour.

Można zauważyć, że trasy wycieczek zaproponowanych przez biura turystyczne w wymienionych ofertach są do siebie dość podobne. Oczywiście jednym z miejsc uwzględnionych we wszystkich planach jest stolica kraju - Dublin i znajdujące się w nim obiekty, takie jak: katedra św. Patryka czy Trinity College. Do grupy powtarzających się atrakcji należy zaliczyć również Klify Moheru, czy też trasę wzdłuż wybrzeża Oceanu Atlantyckiego - Pierścień Kerry wraz ze znajdującym się na niej dworem Muckross House. We wszystkich trzech ofertach pojawił się zamek Rock of Cashel oraz miejscowość Bunratty z mieszczącym się w niej średniowiecznym zamkiem i odtworzoną XIX-wieczną wioską.

Jednocześnie należy zaznaczyć, że każda z wycieczek zawierała w programie miejsca czy obiekty, które nie występują w planach tras wycieczek $\mathrm{z}$ dwóch pozostałych ofert. $\mathrm{W}$ biurze podróży Itaka turyści mogli zwiedzić klasztor św. Kevina znajdujący się w Dolinie Glendalough w górach Wicklow, oraz zamek Kilkenny. Oferta biura podróży Rainbow miała w swoim programie wycieczkę na wyspę Inishmore wraz ze znajdującym się na niej fortem Dun Aengus oraz kościołem Teampall Bheanain. 
W programie biura podróży Logos Tour znajdowało się miasto Cork, a turyści mieli możliwość spacerowania po jego najciekawszych ulicach, czyli m.in.: French Church Street, Carey's Lane lub St. Patrick Street.

\section{Kształtowanie się cen ofert wyjazdów turystycznych do Irlandii}

Koszty ofert turystycznych w ciągu badanego okresu zmieniały się w dość dynamiczny sposób w biurach podróży Itaka i Rainbow, natomiast biuro Logos Tour zaproponowało niezmienną cenę 5900 zł za osobę. Poniżej przedstawiono analizę cen ofert wyjazdów turystycznych do Irlandii w okresie 28.11.2017-4.04.2018 r.

Biuro podróży Itaka oferuje najniższą cenowo ofertę wyjazdu turystycznego do Irlandii spośród wymienionych biur podróży. Jego ceny nie przekraczają 4400 zł.

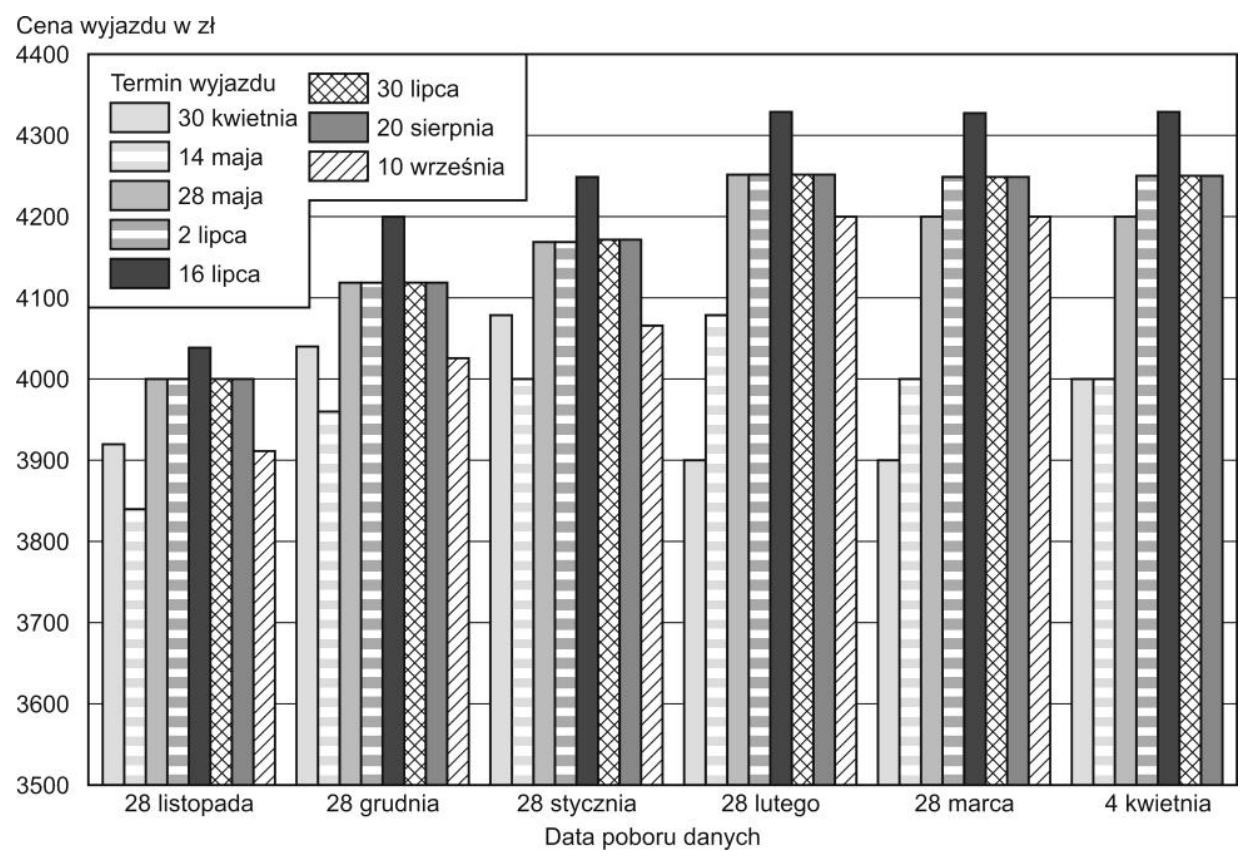

Rys. 1. Ceny wycieczek do Irlandii oferowanych od 28.11.2017 r. do 4.04.2018 r. w biurze podróży Itaka

Źródło: opracowanie własne na podstawie danych ze strony internetowej biura podróży Itaka 
Na wykresie (rys. 1) można zaobserwować, że najdroższe są oferty w okresie lipiec-sierpień (od 4200 zł do 4330 zł). Bez względu na termin turnusu ceny wzrastały do końca lutego. W przypadku turnusów lipcowych i kolejnych stabilizowały się one na wysokim poziomie $(4200 \mathrm{zl}$ i powyżej), w przypadku turnusów majowych, po uzyskaniu najwyższych wartości, w lutym zaczęły spadać.

Rys. 1 ukazuje, że cena pierwszego turnusu, tj. 30.04.-8.05., jest inna niż $\mathrm{w}$ następnych terminach oferowanych przez biuro. Wzrastała ona do końca stycznia, by w kolejnym miesiącu zmaleć o prawie 200 zł. Po obniżce utrzymywała się na tym samym poziomie do końca marca (w marcu w katalogu zamieszczona była jako oferta last minute). Na początku kwietnia można dostrzec jej wzrost o 100 zł (przestała być ofertą last minute).

W nieco inny sposób kształtowały się koszty wyjazdów turystycznych oferowanych przez biuro podróży Rainbow. W analizowanym okresie ceny zmieniały się $\mathrm{w}$ przedziale od ok. $5550 \mathrm{zł} \mathrm{w}$ listopadzie za turnus wrześniowy do ok. 6370 zł w marcu za ostatni turnus czerwcowy. Dwa pierwsze turnusy nie były już dostępne w sprzedaży $w$ marcowej ofercie turystycznej tego biura. Patrząc na wykres (rys. 2), można zauważyć, że

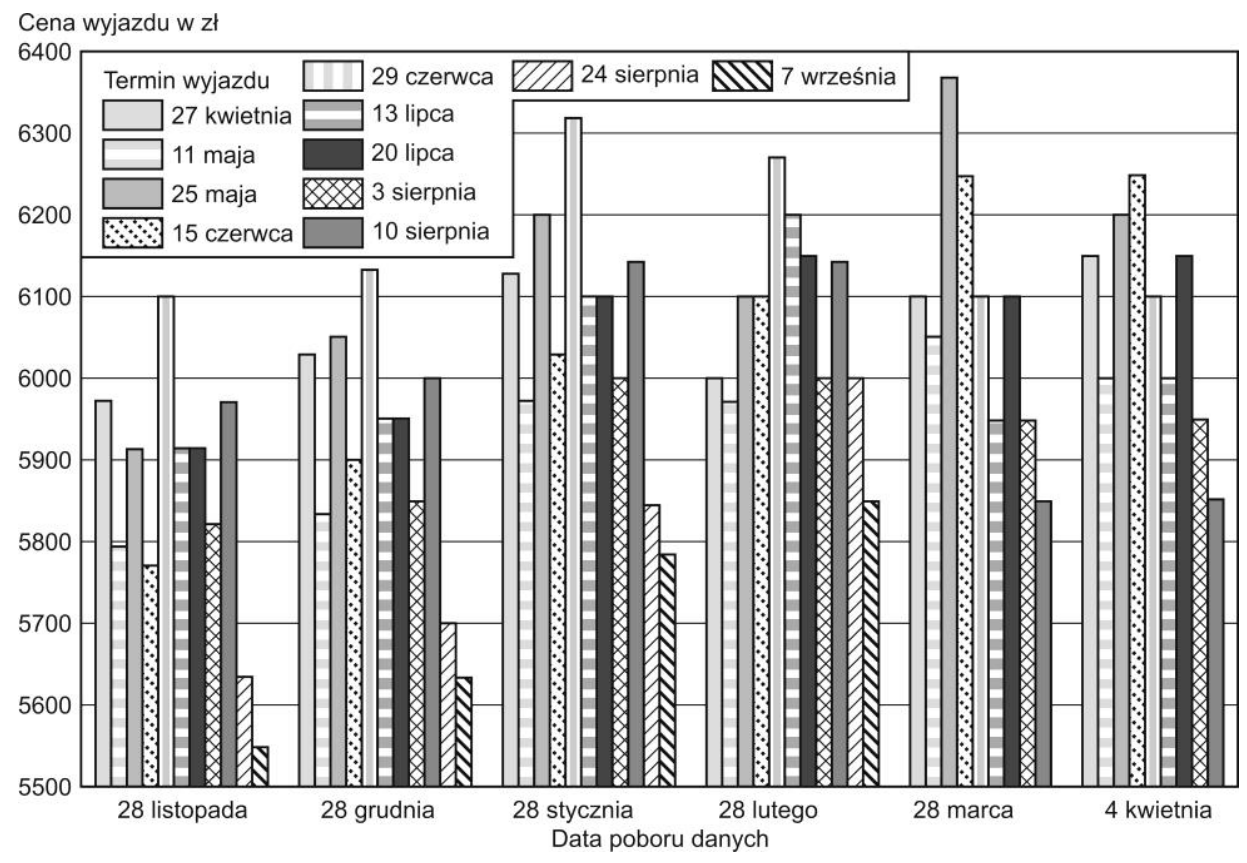

Rys. 2. Ceny wycieczek do Irlandii w biurze podróży Rainbow w 2018 r. Źródło: opracowanie własne na podstawie danych ze strony internetowej biura 
ceny pierwszych turnusów z okresu kwiecień-czerwiec wzrastały do końca stycznia, by $w$ następnym miesiącu spaść. Obniżone ceny $\mathrm{z}$ oferty lutowej, w zależności od turnusu, utrzymywały się przez następny miesiąc na tym samym poziomie lub wzrastały. Ceny turnusów pojawiających się w ofercie w okresie lipiec-wrzesień wzrastały do końca lutego, a następnie w kolejnych miesiącach przeważnie stabilizowały się lub ulegały nieznacznym wahaniom.

Biuro turystyczne Logos Tour oferowało trzy turnusy $w$ Irlandii, $t \mathrm{j}$.: 21-28.05.2018 r., 2-9.07.2018 r. oraz 30.07.-6.08.2018 r. Cena we wszystkich trzech turnusach była niezmienna i utrzymywała się na poziomie $5900 \mathrm{zł}$.

Porównując ceny z listopadowej oferty biura podróży Itaka w 2017 i 2018 r. (tab. 4), można zauważyć, że wyjazd w pierwszym turnusie (29.04-07.05.2019 r.) jest tańszy od proponowanego przez biuro $\mathrm{w}$ tym samym turnusie $w$ roku wcześniejszym (tj. 30.04-08.05.2018 r.) i jego cena jest niższa o ponad $3 \%$ od ceny z roku poprzedniego. Największy spadek ceny między ofertami z listopada w 2017 i 2018 r. można zauważyć w odniesieniu do turnusu odbywającego się w połowie maja. Koszt tej wycieczki jest w tym terminie niższy o prawie $9 \%$ w porównaniu do kosztu proponowanego za ten turnus w roku wcześniejszym. Największy wzrost ceny widać w przypadku turnusu odbywającego się w połowie sierpnia. $\mathrm{W}$ tym przypadku cena $\mathrm{z}$ bieżącego roku jest wyższa o ponad $10 \% \mathrm{w}$ stosunku do ceny proponowanej za ten turnus $\mathrm{w}$ roku poprzednim.

Tab. 4. Porównanie cen wycieczek do Irlandii, organizowanych przez biuro podróży Itaka w listopadzie 2017 i 2018 r.

\begin{tabular}{|c|c|c|c|c|}
\hline \multicolumn{2}{|c|}{28 listopada 2017 r. } & \multicolumn{2}{c|}{24 listopada 2018 r. } & \multirow{2}{*}{$\begin{array}{c}\text { Różnica } \\
\text { w cenie (\%) }\end{array}$} \\
\hline termin wyjazdu & cena za osobę (zł) & termin wyjazdu & cena za osobę (zł) & -3,3 \\
\hline 30.04 .2018 r. & 3919 & 29.04 .2019 r. & 3789 & $-8,9$ \\
\hline 14.05 .2018 r. & 3839 & 20.05 .2019 r. & 3499 & - \\
\hline 28.05 .2018 r. & 3999 & - & - & - \\
\hline- & - & 17.06 .2019 r. & 4169 & $+8,3$ \\
\hline 02.07 .2018 r. & 3999 & 01.07 .2019 r. & 4329 & $+7,2$ \\
\hline 16.07 .2018 r. & 4039 & 15.07 .2019 r. & 4329 & $+8,3$ \\
\hline 30.07 .2018 r. & 3999 & 29.07 .2019 r. & 4329 & $+10,3$ \\
\hline 20.08 .2018 r. & 3999 & 12.08 .2019 r. & 4409 & - \\
\hline- & - & 26.08 .2019 r. & 3749 & $-3,1$ \\
\hline 10.09 .2018 r. & 3909 & 09.09 .2019 r. & 3789 & \\
\hline
\end{tabular}

Źródło: opracowanie własne na podstawie danych pobranych ze strony internetowej biura podróży Itaka. 
Porównując oferty turystyczne wyjazdów do Irlandii w listopadzie w biurze podróży Rainbow z lat 2017 i 2018 (tab. 5), można zauważyć, że ceny z 2018 r. przeważnie mają tendencję spadkową w stosunku do proponowanych $\mathrm{w}$ tym samym okresie $\mathrm{w}$ roku poprzednim. Tylko dwa turnusy tegorocznej oferty turystycznej kosztowały się drożej niż zeszłoroczne $\mathrm{w}$ tym terminie, a wzrost wahał się $\mathrm{w}$ granicach $1,5 \%$. Najniższa cena $\mathrm{w}$ listopadzie 2018 r. wynosiła 5451 zł za osobę - w przypadku terminu majowego. Turnus ten był prawie o $8 \%$ tańszy od zeszłorocznego.

Tab. 5. Porównanie cen wycieczek do Irlandii, organizowanych przez biuro podróży Rainbow w listopadzie 2017 i 2018 r.

\begin{tabular}{|c|c|c|c|c|}
\hline \multicolumn{2}{|c|}{ 28 listopada 2017r. } & \multicolumn{2}{c|}{ 24 listopada 2018 r. } & \multirow{2}{*}{$\begin{array}{c}\text { Różnica } \\
\text { w cenie (\%) }\end{array}$} \\
\cline { 1 - 4 } termin wyjazdu & cena za osobę (zł) & termin wyjazdu & cena za osobę (zł) & - \\
\hline- & - & 17.04 & 5780 & $-4,9$ \\
\hline 27.04 & 5971 & 24.04 & 5680 & $+1,5$ \\
\hline 11.05 & 5795 & 01.05 & 5880 & $-7,8$ \\
\hline 25.05 & 5914 & 22.05 & 5451 & $-3,8$ \\
\hline 15.06 & 5769 & 19.06 & 5551 & - \\
\hline 29.06 & 5914 & - & - & $-6,0$ \\
\hline 13.07 & 5914 & 03.07 & 5561 & $-4,8$ \\
\hline 20.07 & 5914 & 17.07 & 5630 & $-7,6$ \\
\hline 03.08 & 5821 & 07.08 & 5380 & $+1,0$ \\
\hline 10.08 & 5901 & 14.08 & 5961 & $-6,3$ \\
\hline 24.08 & 5633 & 21.08 & 5280 & $-3,0$ \\
\hline 07.09 & 5548 & 04.09 & 5380 & - \\
\hline- & - & 18.09 & 5230 & \\
\hline
\end{tabular}

Źródło: opracowanie własne na podstawie danych pobranych ze strony internetowej biura podróży Rainbow.

Tab. 6. Porównanie oferty turystycznej wyjazdów do Irlandii, organizowanych przez biuro podróży Logos Tour w listopadzie 2017 i 2018 r.

\begin{tabular}{|c|c|c|c|c|}
\hline \multicolumn{2}{|c|}{28 listopada 2017r. } & \multicolumn{2}{c|}{ 24 listopada 2018 r. } & \multirow{2}{*}{$\begin{array}{c}\text { Różnica } \\
\text { w cenie (\%) }\end{array}$} \\
\hline termin wyjazdu & cena za osobę (zł) & termin wyjazdu & cena za osobę (zł) & - \\
\hline- & - & 27.04 .2019 r. & 5990 & - \\
\hline 21.05 .2018 r. & 5900 & - & - & 1,5 \\
\hline 02.07 .2018 r. & 5900 & 01.07 .2019 r. & 5990 & 1,5 \\
\hline 30.07 .2018 r. & 5900 & 29.07 .2019 r. & 5990 & \multicolumn{2}{|c}{} \\
\hline
\end{tabular}

Źródło: opracowanie własne na podstawie danych pobranych ze strony internetowej biura podróży Logos Tour. 
Ceny oferty turystycznej na wyjazdy do Irlandii biura podróży Logos Tour wzrosły o $90 \mathrm{zł} \mathrm{w}$ stosunku do roku wcześniejszego. Tak jak w 2017 r. w ofercie listopadowej biura znalazły się trzy terminy wyjazdów (tab. 6).

$Z$ analizy cen i liczby turnusów proponowanych przez badane biura turystyczne wynika, że wycieczki do Irlandii są atrakcyjne dla polskich turystów. Liczba turnusów zarówno w biurze podróży Itaka, jak i Rainbow zwiększyła się w stosunku do oferty ubiegłorocznej o jeden dodatkowy. Kolejnym faktem świadczącym o dużym zainteresowaniu tą destynacją jest ogólna liczba turnusów oferowana przez biura podróży. Itaka w ofercie na 2018 r. proponowała klientom osiem terminów, a Rainbow - aż 11. W 2019 r. oba biura zwiększyły liczbę turnusów o jeszcze jeden dodatkowy wyjazd, w wyniku czego na nadchodzący sezon Itaka proponuje 9 terminów wyjazdów do Irlandii, a Rainbow - 11. Biuro podróży Logos Tour zarówno w ofercie na 2018 r., jak i 2019 r. posiada stałą liczbę turnusów wyjazdowych - trzy terminy.

\section{Propozycja autorskiej wycieczki tematycznej}

Oferty proponowane przez analizowane biura turystyczne opierały się na zwiedzaniu przez turystów najbardziej znanych i rozpoznawalnych miejsc na terenie Irlandii. Nie było motywu przewodniego, który połączyłby występujące na trasie obiekty.

Autorska oferta turystyczna przedstawiona w niniejszym artykule to siedmiodniowa wycieczka tematyczna „Irlandia na dużym ekranie". Trasa tego wyjazdu obejmuje najciekawsze miejsca Irlandii, pokazane w filmach w ostatnim 70-leciu. Podczas wycieczki turyści mogą się zapoznać $\mathrm{z}$ miejscami wykorzystanymi $\mathrm{w}$ produkcjach filmowych znanych na całym świecie, jak np. Szeregowiec Ryan, Braveheart - Waleczne Serce lub Gwiezdne wojny: Przebudzenie Mocy, oraz odwiedzić miejsca pojawiające się $\mathrm{w}$ produkcjach familijnych i mniej znanych filmach, do których możemy zaliczyć m.in.: Narzeczona dla księcia czy Ella Zaklęta.

Podczas 7-dniowego wyjazdu (tab. 7) planowane do odwiedzenia są m.in. miejsca związane $\mathrm{z}$ wielkimi produkcjami światowymi - Braveheart - Waleczne Serce, Harry Potter i Ksiąze Pótkrwi czy Gwiezdne wojny: ostatni Jedi. 
Tab. 7. Plan trasy po Irlandii zaproponowanej w autorskiej ofercie turystycznej

\begin{tabular}{|c|l|}
\hline Dzień & \multicolumn{1}{c|}{ Zwiedzane miejsca } \\
\hline 1 & $\begin{array}{l}\text { Dublin - Once (2006), Love, Rosie (2014), Edukacja Rity (1983) } \\
\text { Zamek w Trim - Braveheart - Waleczne Serce (1995) } \\
\text { Opactwo w Bective - Braveheart - Waleczne Serce (1995) } \\
\text { Tullamore - Zamek Charleville - Zakochana Jane (2007) }\end{array}$ \\
\hline 2 & $\begin{array}{l}\text { Leenane - Pole (1990) } \\
\text { Ashford Castle - Spokojny cztowiek (1952) } \\
\text { Quiet Man Bridge - Spokojny cztowiek (1952) } \\
\text { The Quiet Man Museum } \\
\text { Klify Moheru - m. in. Harry Potter i Ksiaże Pótkrwi (2009), Za horyzontem (1992), } \\
\text { Córka Ryana (1970), Człowiek Mackintosha (1973), Na zachód (1992) }\end{array}$ \\
\hline 3 & $\begin{array}{l}\text { Derrynane - Wieki ciemne (1981) } \\
\text { Skellig Michael - Gwiezdne wojny: Przebudzenie Mocy (2015), Gwiezdne wojny: } \\
\text { Ostatni Jedi (2017) } \\
\text { Parknasilla - The Lobster (2015) }\end{array}$ \\
\hline 4 & $\begin{array}{l}\text { Youghal - Moby Dick (1956) } \\
\text { Curracloe Strand - Szeregowiec Ryan (1998), Brooklyn (2015) }\end{array}$ \\
\hline 5 & $\begin{array}{l}\text { Kilruddery House \& Gardens - Moja lewa stopa (1989), Za horyzontem (1992), } \\
\text { Dynastia Tudorów, Camelot } \\
\text { Powerscourt Estate - m.in. Henryk V (1944), Król Artur (2004), Ella Zaklęta (2004), } \\
\text { Hrabia Monte Christo (2002), Dynastia Tudorów, Camelot }\end{array}$ \\
\hline 6 & Park Narodowy Gór Wicklow - PS Kocham cię (2007) \\
\hline 7 & $\begin{array}{l}\text { Dublin - Muzeum Kilmainham Gaol - Wiatr buszujący w jęczmieniu (2006), } \\
\text { Wtoska robota (1969), Michael Collins (1996) }\end{array}$ \\
\hline
\end{tabular}

Źródło: opracowanie własne.

Jednym z pierwszych znanych filmów nagrywanych w Irlandii był Spokojny człowiek (1952) w reżyserii J. Forda, w którym główne role zagrali J. Wayne i M. O'Hara. Większość zdjęć do filmu nakręcono w zamku Ashford Castle w hrabstwie Galway (obecnie 5-gwiazdkowy hotel) oraz w położonej w jego sąsiedztwie wsi Cong (The Quiet Man). Ponadto w filmie uwieczniono Quiet Man Bridge - most nad rzeką Owenriff, znajdujący się w pobliżu drogi N59. Film zdobył dwa Oskary, w tym za najlepsze zdjęcia.

Kilka lat później nadmorska miejscowość Youghal w hrabstwie Cork jako New Bedford stała się tłem scen lądowych kręconych do Moby Dicka (1956). W mieście znajduje się pub, w którym stołowali się aktorzy występujący $\mathrm{w}$ filmie.

Spośród współczesnych produkcji na uwagę zasługuje film Braveheart - Waleczne Serce (1995) w reżyserii M. Gibsona, nagrywany w otoczeniu dwóch obiektów na terenie Irlandii. Pierwszy z nich to Trim Castle (hrab- 
stwo Meath) największy w kraju zamek anglo-normański, w filmie ukazany jako miasto York. Jego budowa rozpoczęła się około 1176 r. i trwała 30 lat. Dla zwiedzających został otwarty w 2000 r. (Trim Castle). Kolejny obiekt to położone $\mathrm{w}$ hrabstwie Meath ruiny poklasztorne $\mathrm{z}$ XV w., będące pozostałościami po średniowiecznym opactwie cystersów Bective Abbey z $1147 \mathrm{r}$.

Wśród miejsc w Irlandii, które często stanowią "scenografię" filmową, można wskazać dwa najbardziej popularne. Powerscourt Estate w hrabstwie Wicklow - dwór wraz z rozciągającym się na terenie 19 ha zespołem ogrodów - występuje w ponad 25 różnych produkcjach filmowo-telewizyjnych, takich jak np.: Henryk V (1944), Król Artur (2004) z C. Owenem i K. Knightley, Ella Zaklęta (2004) czy Hrabia Monte Christo (2002). W posiadłości zostały nakręcone również znane seriale telewizyjne, choćby takie, jak Dynastia Tudorów i Camelot (Movie magic at Powerscourt). Kolejne miejsce to majestatyczne Klify Moheru w hrabstwie Clare - jedna z najczęściej odwiedzanych atrakcji przyrodniczych Irlandii. Ciągnące się na długości $8 \mathrm{~km}$ w linii prostej klify sięgają w najwyższym punkcie $214 \mathrm{~m}$. Stanowią idealną scenerię filmową, co wykorzystano np. w produkcjach: Za horyzontem (1992), w której wystąpili T. Cruise i N. Kidman, Harry Potter i Ksiązé Pótkrwi (2009), Narzeczona dla księcia (1987), Człowiek Mackintosha (1973), Córka Ryana (1970) czy Na zachód (1992) (Cliffs of Moher).

W stolicy Irlandii - Dublinie - również nakręcono wiele filmów. W filmie Once (2006) można podziwiać najpopularniejsze zakątki miasta, m.in.: Grafton Street, George's Street, Temple Bar i St. Stephen's Green. W Love, Rosie (2014) możemy zobaczyć dublińskie lotnisko, natomiast Uniwersytet Trinity College pojawił się m.in. w produkcji Edukacja Rity (1983) z M. Cainem. Ważnym miejscem jest więzienie Kilmainham Gaol, które uwiecznono $\mathrm{w}$ takich filmach, jak: Wiatr buszujacy w jeczmieniu (2006), Wtoska robota (1969) oraz Michael Collins (1996) z L. Neesonem (Ireland on screen..., 2019).

Podczas wyjazdu uczestnicy będą mogli skorzystać z następujących świadczeń: sześć noclegów, sześć śniadań, przejazd autokarem na trasie, przelot, opieka polskojęzycznego pilota oraz ubezpieczenie NW i KL. Cena oferty byłaby zbliżona do oferty proponowanej przez wymienione $\mathrm{w}$ artykule biura turystyczne, a jej różnica wynikałaby jedynie z miejsc i obiektów odwiedzanych na trasie. 


\section{Podsumowanie}

W artykule dokonano analizy ofert wyjazdów turystycznych do Irlandii znajdujących się w polskiej propozycji wyjazdowej. Stwierdzono, że jest ona atrakcyjna dla polskich turystów, co wynika z dość dużej liczby turnusów oferowanych przez biura podróży. Jednakże oferty te są podobne do siebie pod względem doboru miejsc znajdujących się $\mathrm{w}$ planie wycieczki.

Analizując przykłady z wielu miejsc na świecie, należy stwierdzić, że film może znakomicie promować miejsce i stać się „magnesem” przyciągającym turystów. W związku z tym przedstawiono propozycję wycieczki tematycznej opierającej się na turystyce filmowej w Irlandii, będącej planem filmowym wielu wysokobudżetowych produkcji. $\mathrm{Na}$ trasie wycieczki pojawiają się obiekty i miejsca występujące w różnych filmach kręconych na terenie kraju. Trasa przebiega przez wiele hrabstw, tworząc pętlę dookoła kraju. Wydaje się, że oferta ta byłaby ciekawym tematycznym uzupełnieniem oferty istniejącej na rynku.

\section{Bibliografia}

Cliffs of Moher. Pobrane z: https://www.cliffsofmoher.ie/ (20.11.2018).

Dębski, M. (2006). Marka obszarów turystycznych jako element rozwoju turystyki w regionie. Studia i Prace Kolegium Zarządzania i Finansów, 74, 181-197.

Insights. Pobrane z: https://insights.nzherald.co.nz/article/new-zealand-regional-economy/ (20.11.2018).

Ireland on screen: 10 spectacular filming locations to visit in 2019 (2019). Pobrane z: https:/ / www.skyscanner.ie/news/features/10-filming-locations-in-ireland-you-must-visit/ (20.11.2018).

Itaka. Pobrane z: https://www.itaka.pl/wycieczki/irlandia/w-krainie-leprikonow,DUBIRLE. html (20.11.2018).

Jarosz, A. (2018). Atrakcyjność turystyczna Irlandii. Praca licencjacka. Lublin: Uniwersytet Marii Curie-Skłodowskiej w Lublinie.

Kosmulska, J. (red.) (2005). Przewodnik Kieszonkowy Irlandia. Warszawa: Berlitz.

Logos Tour. Pobrane z: https:/ /logostour.pl/irlandia-2018 (20.11.2018).

Londyn. Bond i nie tylko (2017). Pobrane z: http://www.filmowe-szlaki.pl/ 2017/08/02/ londyn/ (20.11.2018).

Movie magic at Powerscourt. Pobrane z: https://powerscourt.com/estate/movies-at-powerscourt (20.11.2018).

Panasiuk, A. (2014). Wymiary oferty na rynku turystycznym. Rozprawy Naukowe Akademii Wychowania Fizycznego we Wroctawiu, 46, 119-128. 
Rainbow. Pobrane z: https://r.pl/irlandia-i-irlandia-polnocna-legendy-wykute-w-skalach/ zakwaterowanie-irp (20.11.2018).

Stasiak, A. (2009). Turystyka literacka i filmowa. W: K. Buczkowska, A. Mikos Von Rohrscheidt (red.), Wspótczesne formy turystyki kulturowej (s. 223-265). Poznań: Akademia Wychowania Fizycznego w Poznaniu.

The Quiet Man. Pobrane z: https:/ / www.ashfordcastle.com/about/the-quiet-man (20.11.2018).

Trim Castle. Pobrane z: http://www.meath.ie/tourism/heritage/heritagesites/trimcastle/ (20.11.2018).

UNWTO. Tourism highlights (2017). Pobrane z: https://www.e-unwto.org/doi/pdf/ 10.18111/ 9789284419029 (20.11.2018).

Wojciechowska, J., Florczak D. (2005). Oferta agroturystyczna łódzkich biur podróży - próba definicji pojęcia. Problemy Turystyki, 1-2, 97-107.

Zmyślony, P. (2001). Wpływ sztuki filmowej na rozwój nowych produktów turystycznych w Polsce. Problemy Turystyki, XXIV (3-4), 21-30.

\title{
PROJEKT OFERTY TURYSTYKI FILMOWEJ JAKO PRÓBA UROZMAICENIA POLSKIEJ OFERTY WYJAZDOWEJ DO IRLANDII W 2018 ROKU
}

\begin{abstract}
Abstrakt: Celem autorki artykułu jest zaproponowanie opartej na turystyce filmowej wycieczki tematycznej, która byłaby próbą urozmaicenia istniejącej oferty wyjazdowej do Irlandii. Artykuł mieści w sobie krótką klasyfikację definicji turystyki filmowej oraz przedstawia zarys jej rozwoju na świecie. Wyniki analizy ofert wyjazdów turystycznych do Irlandii w sezonie 2018 r. świadczą o tym, że Irlandia jest krajem chętnie odwiedzanym przez Polaków. Jednakże dobór miejsc pojawiających się w planach wycieczek w przypadku tej destynacji jest zbliżony do siebie w poszczególnych ofertach. Dostrzegając dużą popularność turystyki filmowej na świecie, w artykule zaprezentowano propozycję wycieczki tematycznej opierającej się na turystyce filmowej w Irlandii. Artykuł powstał na podstawie informacji zawartych $\mathrm{w}$ dostępnej literaturze naukowej, przewodnikach i na portalach internetowych.
\end{abstract}

Słowa kluczowe: Irlandia, oferta turystyczna, turystyka filmowa.

\section{THE PROJECT OF FILM TOURISM OFFER AS AN ATTEMPT TO SPICE THE POLISH TRAVEL OFFER TO IRELAND IN 2018}

\begin{abstract}
The purpose of the article was to present a offer of a theme tour based on film tourism, an attempt to spice the existing travel offer to Ireland. The article contains a short classification of the definition of film tourism and presents an outline of its development in the world. The results of the analysis of tourist travel offers to Ireland in the 2018 season show that Ireland is a country willingly visited by Poles. However, the selection of places appearing in the trip plans on this destination is similar to the individual offers. Recognizing the great popularity of film tourism in the world, the article presents a theme tour based on film tourism in Ireland. The article is based on a review of available scientific literature, guides and online portals.
\end{abstract}

Keywords: Ireland, tourist offer, film tourism, movie tourism. 